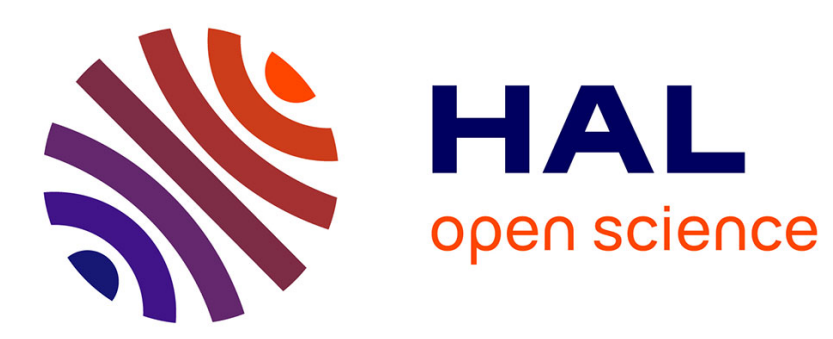

\title{
TIME INCONSISTENCY AND DELAYED RETIREMENT DECISION: THE FRENCH PENSION BONUS.
}

Steve Briand

\section{- To cite this version:}

Steve Briand. TIME INCONSISTENCY AND DELAYED RETIREMENT DECISION: THE FRENCH PENSION BONUS.. CHAIRS DAYS: Insurance, Actuarial Science, Data and Models, Jun 2018, Paris, France. hal-02004085

\section{HAL Id: hal-02004085 \\ https://hal.science/hal-02004085}

Submitted on 1 Feb 2019

HAL is a multi-disciplinary open access archive for the deposit and dissemination of scientific research documents, whether they are published or not. The documents may come from teaching and research institutions in France or abroad, or from public or private research centers.
L'archive ouverte pluridisciplinaire HAL, est destinée au dépôt et à la diffusion de documents scientifiques de niveau recherche, publiés ou non, émanant des établissements d'enseignement et de recherche français ou étrangers, des laboratoires publics ou privés. 


\section{PENSION BONUS AND EX POST EVALUATIONS}

- Ensure the financial sustainability of public pensions funds because of the increase in life expectancy and the demographic shocks.

$\rightarrow$ One financial incentive aiming to postpone individual retirement, the pension bonus: an agent gets a higher pension if he retires beyond his full retirement age (full benefits + an additional proportional bonus)

> The effectiveness is relatively limited:

- The global effect of financial incentives is principally led by informed individuals (Chan and Stevens, 2008).

- In France, men are more responsive to the bonus (Benallah, 2011).

$\rightarrow$ Another (behavioral) explanation, time inconsistency?

\section{WHAT IS TIME INCONSISTENCY IN AN INTERTEMPORAL \\ TRADE-OFF?}

Discounting function of a time-consistent agent (exponential discounting):

$$
\delta^{t}=\frac{1}{(1+r)^{t}} \quad \text { as } \quad U_{t}=u_{t}+\delta u_{t+1}+\delta^{2} u_{t+2}+\ldots
$$

With $r$ the discounted rate

But, for a time-inconsistent agent (hyperbolic discounting), a decreasing discounted rate with time:

$\rightarrow$ Impatient in the short-term and more patient in the longterm (Thaler, 1981). He planned to do an action, but as this action gets near, the agent changes his decision.

The tractable quasi-hyperbolic function (Laibson, 1997):

$$
\beta \delta^{t}=\frac{\beta}{(1+r)^{t}} \quad \text { as } \quad U_{t}=u_{t}+\beta \delta u_{t+1}+\beta \delta^{2} u_{t+2}+\ldots
$$

With the present-bias $0<\beta \leq 1$. The lower $\beta$ is, the more the agent is time-inconsistent: overweighting of immediate outcome (utility or disutility).

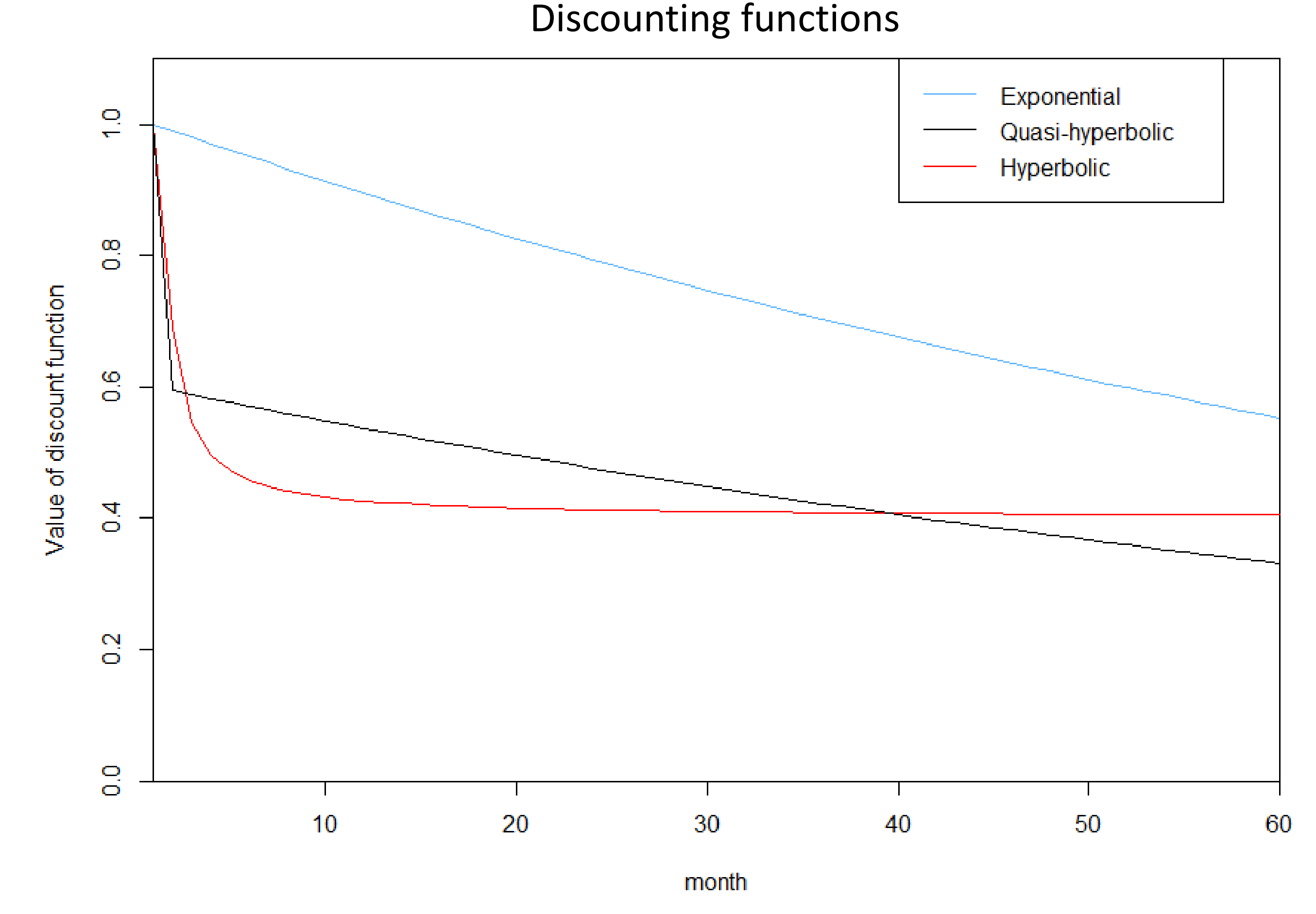

\section{THE DATA}

The French "motivations de départ en retraite" survey (DREES, 2014) on new retirees between July 2012 and June 2013, merged with administrative data:

> Cohorts: 1948 - (first quarter) 1952

> Who were employees of the private and public sectors, nonactive civil servants or self-employed and who have contributed at least one year to the private sector employee pension fund during their careers.

\section{THE MEASURE OF TIME PREFERENCES}

Two ordinal synthetic scores:

$>$ Short-term impatience (proxy of $\beta$ )

$>$ Long-term impatience (proxy of $\delta$ )

Based on questions on motivations to retire (4 modality scale "strongly agree", "agree", "disagree", "strongly disagree"). For instance:

> "You decided to retire because you had reached the Early Retirement Age (ERA)"

$\rightarrow$ Linked to short-term impatience (4 items)

$>$ "You decided to retire because you wanted to enjoy retirement as long as possible"

$\rightarrow$ Linked to long-term impatience (5 items)

The aggregation of answers constitute two final scores, standardized, with 0 mean and a variance of 1 .

\section{ECONOMETRIC STRATEGY}

A recursive bivariate probit model with two latent dependent variables:

$$
\begin{cases}y_{1}^{*}=X_{1} \beta_{1}+\alpha Z+\varepsilon_{1}, & y_{1}=1\left(y_{1}^{*}>0\right), \\ y_{2}^{*}=X_{2} \beta_{2}+\gamma y_{1}+\varepsilon_{2}, & y_{2}=1\left(y_{2}^{*}>0\right),\end{cases}
$$

with $y_{1}$ the bonus knowledge, $y_{2}$ delayed retirement to get the bonus and $Z$ a set of instruments.

$$
\left(\begin{array}{l}
\varepsilon_{1} \\
\varepsilon_{2}
\end{array}\right) \rightarrow N\left(\left(\begin{array}{l}
0 \\
0
\end{array}\right),\left(\begin{array}{ll}
1 & \rho \\
\rho & 1
\end{array}\right)\right)
$$

with $\rho$ the correlation between the error terms.

$\rightarrow$ This specification allows to control the likely endogeneity of the bonus knowledge $\left(y_{1}\right)$.

\section{RESULTS}

Both short-term and long-term impatience are significant and impact negatively the probability of retiring with pension bonus. $\rightarrow$ A time-inconsistent agent has a lower probability to delay his retirement to get the bonus compared to a timeconsistent agent.
By fixing both short-term and long-term impatience, an average difference in predicted probabilities of -31.60 ( $55.41 \%$ compared to $23.81 \%$ ) between the most time-consistent agent and the most time-inconsistent agent.

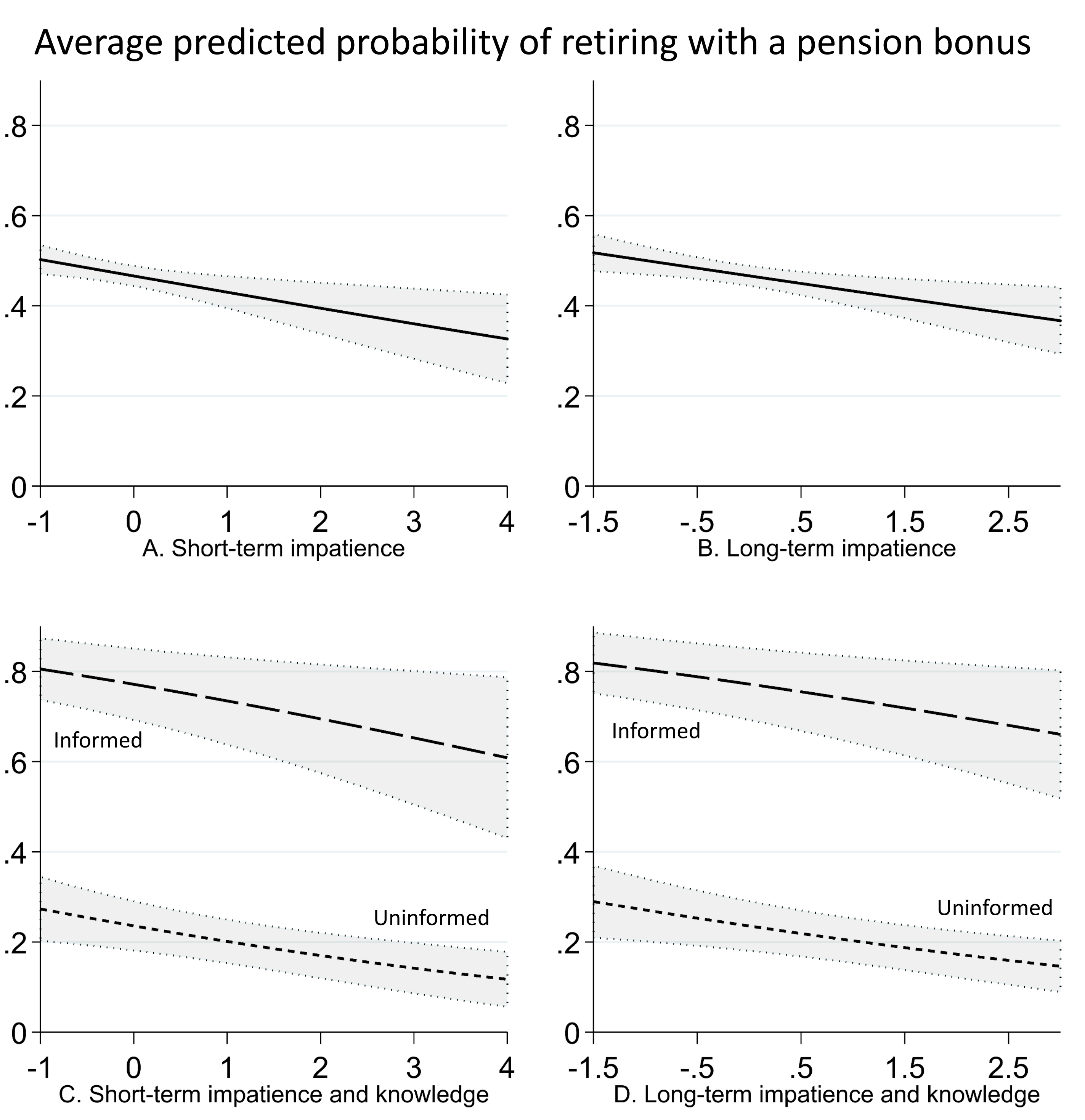

The endogeneity of the bonus knowledge is confirmed $(\rho<0)$.

\section{CONCLUSION}

> Time inconsistency is a key determinant of the decision not to delay retirement to get the bonus: another explanation of the (relatively) limited impact of financial incentives aiming to postpone retirement.

> We need to integrate nonstandard preferences in individual retirement analyses.

- Considering nonstandard preferences can improve public information and the efficiency of public policies (Thaler and Sunstein, 2008)

\section{REFERENCES}

Re départ en retraite et réforme de 2003. Les effets de la surcote. Economie et statistique 441-442: $79-99$.

- Chan and Stevens, 2008. What you don't know can't help you: pension knowledge and . Laibson, 1997. Golden eggs and hyperbolic discounting. The Quarterly Journal of Economics 112 (2): 443-478.

Thaler, 1981. Some empirical evidence on dynamic inconsistency. Economics Letters 8(3): 201-207.

Thaler and Sunstein, 2008. Nudge: Improving decisions about health, wealth, and happiness. New Haven, CT: Yale University Press.

\section{LABORATOIRE}

